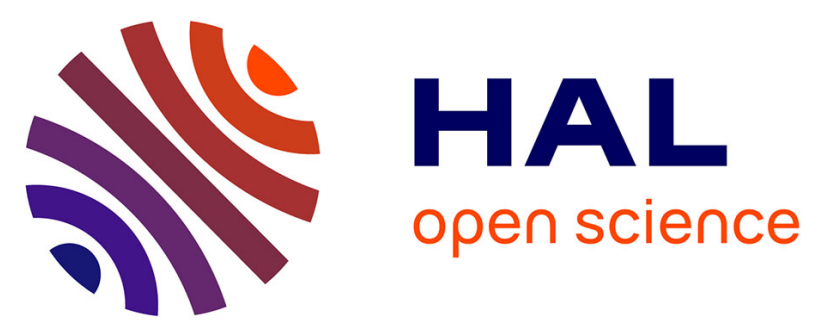

\title{
Vegetation history and human-environment interactions through the late Holocene in Konar Sandal, SE Iran
}

Karolina Gurjazkaite, Joyanto Routh, Morteza Djamali, Alireza Vaezi, Yoann Poher, Abdolmajid Naderi Beni, Vahid Tavakoli, Henrik Kylin

\section{- To cite this version:}

Karolina Gurjazkaite, Joyanto Routh, Morteza Djamali, Alireza Vaezi, Yoann Poher, et al.. Vegetation history and human-environment interactions through the late Holocene in Konar Sandal, SE Iran. Quaternary Science Reviews, 2018, 194, pp.143-155. 10.1016/j.quascirev.2018.06.026 . hal-01844143

\section{HAL Id: hal-01844143 \\ https://hal-amu.archives-ouvertes.fr/hal-01844143}

Submitted on 25 Jul 2018

HAL is a multi-disciplinary open access archive for the deposit and dissemination of scientific research documents, whether they are published or not. The documents may come from teaching and research institutions in France or abroad, or from public or private research centers.
L'archive ouverte pluridisciplinaire HAL, est destinée au dépôt et à la diffusion de documents scientifiques de niveau recherche, publiés ou non, émanant des établissements d'enseignement et de recherche français ou étrangers, des laboratoires publics ou privés. 
Vegetation history and human-environment interactions through the late Holocene in Konar Sandal, SE Iran

Karolina Gurjazkaite, Joyanto Routh, Morteza Djamali, Alireza Vaezi, Yoann Poher, Abdolmajid Beni, Vahid Tavakoli, Henrik Kylin 


\title{
Vegetation history and human-environment interactions through the late Holocene in Konar Sandal, SE Iran
}

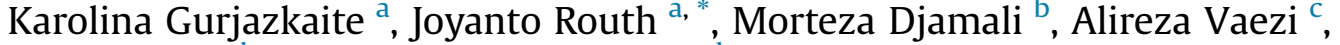 \\ Yoann Poher ${ }^{\mathrm{b}}$, Abdolmajid Naderi Beni ${ }^{\mathrm{d}}$, Vahid Tavakoli ${ }^{\mathrm{e}}$, Henrik Kylin ${ }^{\mathrm{a}}$ \\ a Department of Thematic Studies - Environmental Change, Linköping University, 58183, Linköping, Sweden \\ ${ }^{\mathrm{b}}$ Aix Marseille Univ, Univ Avignon, CNRS, IRD, IMBE (Institut Méditerranéen de Biodiversité et d'Ecologie), Aix-en-Provence, France

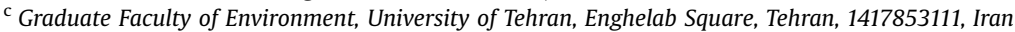 \\ d Iranian National Institute for Oceanography and Atmospheric Sciences, Etemadzadeh St, Tehran, 141181 3389, Iran \\ e School of Geology, College of Science, University of Tehran, Enghelab Square, Tehran, 1417853111, Iran
}

\section{A R T I C L E I N F O}

Article history:

Received 12 February 2018

Received in revised form

26 June 2018

Accepted 27 June 2018

\section{Keywords:}

Agro-pastoralism

Climate

Halil Rud

Late Holocene

Peat

Pollen

Vegetation history

\begin{abstract}
A B S T R A C T
The Jiroft valley, situated on banks of the Halil Rud developed as an important agricultural and trading center during the Early Bronze Age. Known for its famous steatite sculptures and clay pottery, the first settlement in Konar Sandal collapsed around 3rd millennium BCE. A second shorter, but major phase of occupation in the settlement occurred towards the end of 2nd millennium BCE. A 250-cm long peat sequence near the archaeological complex at Konar Sandal was investigated to reconstruct the humanenvironment history using palynological, sedimentological and geochemical data. With a basal age of 4 $\mathrm{ka}$, the core traces the hydroclimatic changes and human activities that started just after large scale abandonment of Konar Sandal and extends from the late Bronze Age to the Mongol invasion. The results show that Jiroft had an arid dry climate dominated by the Saharo-Sindian open pseudo-savanna vegetation. However, due to human clearance and intensified agro-sylvo-pastoral activities, and climatic factors, the land-cover shifted from open xeric scrublands to a more open degraded landscape. The principal human occupation was cereal cultivation and herding. However, it is likely that during the more arid periods, communities retreated and abandoned agriculture, facilitating successional processes. Such droughts occurred around 4.0-3.8 ka and 3.4-2.8 ka and are related to the Siberian Anticyclonic system. Declining Artemisia and shrubs indicate milder climates $c a$. 3.8-3.4 ka and 2.8-0.6 ka. The latter period that started with the rule of the Persian empires (550-650 BCE), and continued through the Islamic era, coincides with intensive human activities, and the highest degradation of vegetation.
\end{abstract}

\section{Introduction}

During the 3rd millennium BCE, Early Bronze Age (EBA) urban centers rose and flourished in Kerman and neighboring provinces in southeastern Iran. Some of the most important settlements were based in Shahr-i sokhta, Tepe Yahya, Bampur, Shahdad, Tal-i Iblis, and Konar Sandal (Dyson and Voigt, 1990; Madjidzadeh and Pittman, 2008; Lawler, 2011). These centers were vital for trade, agriculture and cultural exchange that flourished in the region.

In 2001, massive flooding exposed a historic and mostly intact cemetery located in Konar Sandal (KS) situated on the banks of the

\footnotetext{
* Corresponding author.

E-mail address: joyanto.routh@liu.se (J. Routh).
}

Halil Rud (rud means river in Persian) in south of Jiroft (Fig. 1; Madjidzadeh and Pittman, 2008). The discovery unfortunately coincided with systematic looting and illegal trading of precious artifacts retrieved from the site by local villagers (Madjidzadeh and Pittman, 2008). Scrutiny of some of these artifacts confiscated by the Iranian government in 2001 revealed that people in KS, developed the unique, so-called 'Jiroft' artistic style. This feature was evident in the steatite engravings and clay pottery (Madjidzadeh, 2003; Madjidzadeh and Pittman, 2008). Further, it was claimed that people in Jiroft even had an early writing system (Madjidzadeh and Pittman, 2008; Desset, 2014), but this is debated. Since the 1970s, archaeological surveys conducted by the Iranian teams with participants from different countries particularly from USA and France discovered the rich heritage and historical significance. Multiple expeditions by French archeologists including those 


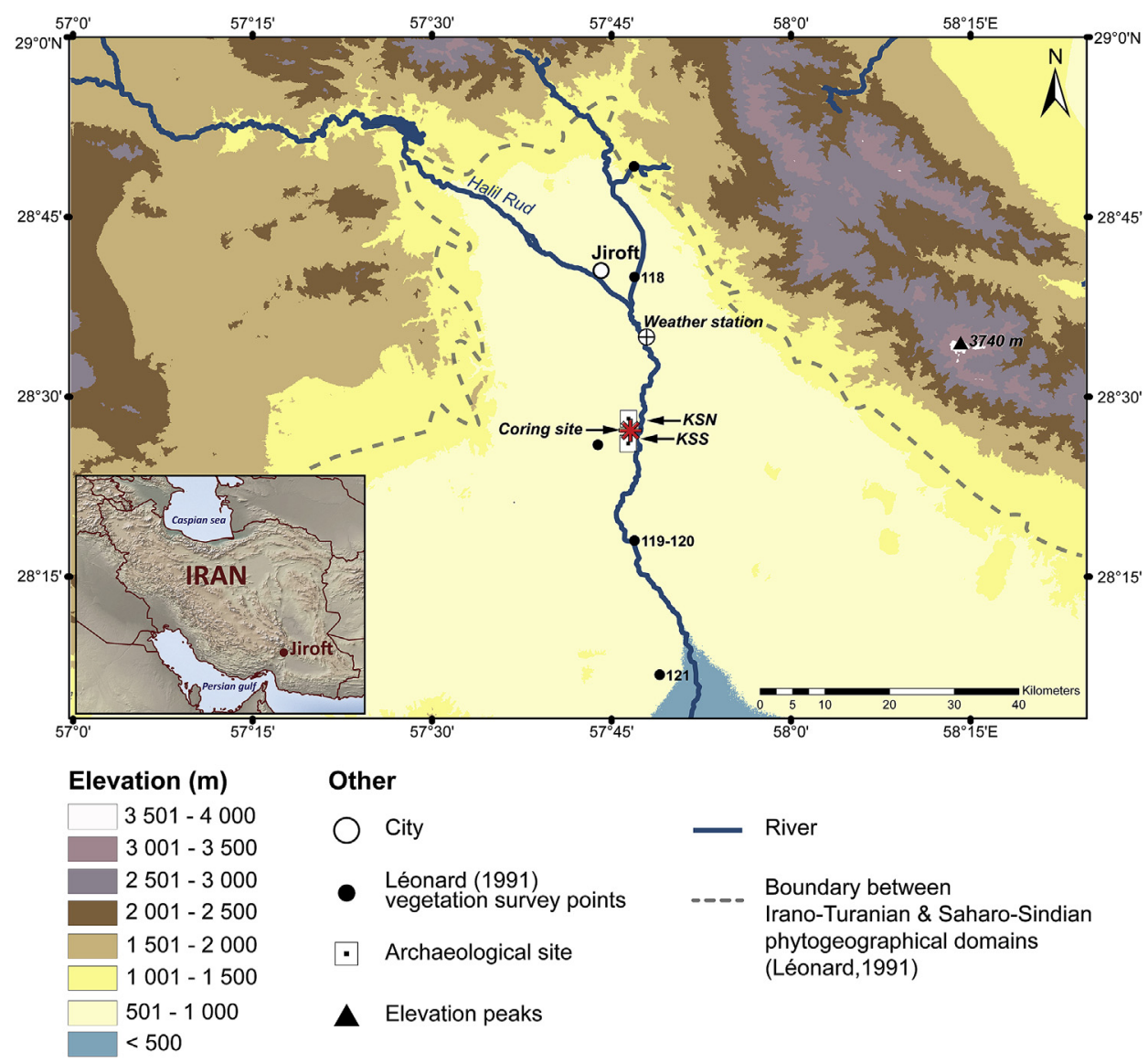

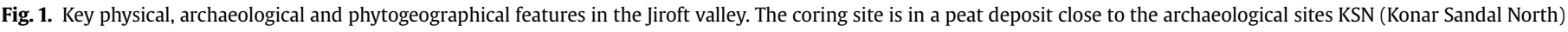
and KSS (Konar Sandal South). The inset showing the physiographic map of Iran in the bottom left corner shows location of the Jiroft valley in southeastern Iran.

in KS between 2001 and 2006 established that the Jiroft culture must have been a socio-economically advanced agrarian society with extended trade links with other cultural centers during the 3rd millennium BCE. Agricultural activities in the community included growing cereals (wheat, barley), fruits (dates and grapes), and domestication of animals (bovines, goats, sheep and horses) that are well-preserved in the archaeological surveys conducted by Mashkour et al. (2013). The notable discoveries of Jiroft-style steatite vessels in Sumerian cities (Steinkeller, 1982) and a seal with Indus style iconographic components found in KS (Vidale and Frenez, 2015), validates the importance of this settlement as an EBA trade center. The archaeological discoveries captivate our imagination about flourishing agricultural practices, ancient trade routes, and business links that existed between these distant cities ca. 4000 years ago.

Nevertheless, during the late 3rd millennium BCE, KS and the other EBA settlements in the region steadily declined (Madjidzadeh and Pittman, 2008; Lawler, 2011). Such a collapse may have occurred due to the possible impact of the 4.2 ka regional drought, which is believed to have caused the decline and collapse of agrarian societies in the earlier Akkadian Empire and the Old Kingdom of Ancient Egypt (Weiss et al., 1993; Booth et al., 2005). Further to the east, the Indus Valley Civilization (Dixit et al., 2014; Sarkar et al., 2016; Dutt et al., 2018) and the Early Bronze Age cultures in China (Gao et al., 2007) were also affected. This led Ponton et al. (2012) to conclude that the $4.2 \mathrm{ka}$ event was perhaps the beginning of a steady and gradual decline noted across different agrarian societies and urban nation states. Poor rainfall and consequential desertification could have disrupted agriculture, and eventually led to the decline and/or abandonment of these societies.

The harsh environmental conditions combined with complex phytogeographic settings imply that data from paleoenvironmental studies are important to understand the cultural dynamics and its advancement in southeastern Iran home to many EBA settlements. To date the key investigations in KS have focused on archaeological findings (Madjidzadeh and Pittman, 2008), bioarchaeological surveys (Mashkour et al., 2013) and geomorphology (Fouache et al., 2005). However, lack of multi-proxy high-resolution paleoenvironmental data from the region hampers our understanding of the role of environment on ephemeral communities and their societal interactions. Moreover, the general lack of suitable sedimentary archives, e.g., wetlands, caves, and lake systems pose another level of complexity for paleoclimate studies in these dry and generally barren regions. As a result, we know very little about how the historic societies in this region coped with aridity, their cultivation practices, and adaptation to episodic wet or dry periods during late Holocene Here, we report a detailed palynological study reconstructed from a sediment core retrieved from a peat deposit near the excavation site in KS (Fig. 1) that will be further supported by other sedimentological and geochemical proxies. The aims of this paper are to: (1) establish hydroclimatic changes and landscape evolution in the Jiroft valley during the late Holocene, and (2) reconstruct the human-environment interactions and the history of agro-pastoralism in relation to environmental changes in southeastern Iran. As a first multi-proxy high-resolution study from the region, our investigation provides important data on climate and its impacts on the socio-cultural and physical changes in the region, and its continued development over the last 4000 years. 


\section{Site description}

\subsection{Physical settings}

Konar Sandal is an archaeological site situated approximately $25 \mathrm{~km}$ south of the city of Jiroft, in Kerman province, SE Iran (Fig. 1). The site is situated on the fluvial plains of the Halil Rud, roughly at $570 \mathrm{~m}$ a.s.l. and ca.1 $\mathrm{km}$ to the west of the Halil Rud. The Jiroft valley descends from two mountain ranges, the Kerman Massif to the north-west, and the Barez Mountains in the east, which rise to an elevation of $3740 \mathrm{~m}$ a.s.l. (Fouache et al., 2005).

The Halil Rud originates in the Kerman Mountains and flows in south-easterly direction for $c a .400 \mathrm{~km}$ before draining into Lake Jazmurian (Hamun-e Jazmurian), an endorheic playa. During the Early Bronze and Iron Ages, the river's original course was to the west of its present-day location (Fouache et al., 2005). The river waters are fed by rain and melting snow of the Barez and the Kerman Mountains. Due to variable input of freshwater at the source, the hydrological regime of the Halil Rud is characterized by intermittent flows, displaying high inter-annual variability that may manifest itself through flooding events (Fouache et al., 2005). Construction of dams in the upper parts of the river has resulted in irregular flow on the downstream side (Mashkour et al., 2013), particularly into Lake Jazmurian, which currently remains dry during most times of the year.

The groundwater table in the alluvial plain is close to the surface that creates artesian wells. which are an important water resource for agriculture. Spring water chemistry changes from freshwater near Jiroft to brackish conditions near KS, because of increase in gypsum and other evaporite deposits (Fouache et al., 2005). While the wider landscape consists mainly of xeric vegetation and scrubland, there are isolated pockets of small wetlands and peat sequences scattered around the region. Agriculture flourishes where freshwater is readily available, and it is distributed through a network of canals. The important aspect about the general setting of the region is that it is very sensitive to the availability of surface water from the mountains and Halil Rud which influences vegetation, land-use practices, and human subsistence in otherwise a very barren landscape.

\subsection{Climate}

Jiroft is in a tropical desert-like bioclimatic region (i.e. a region characterized by very low annual precipitation for at least seven months and mean precipitation is less than mean temperature; Djamali et al., 2011). Data from the meteorological station located ca. $10 \mathrm{~km}$ south of Jiroft shows that the average annual temperature in the region presently is $26.3^{\circ} \mathrm{C}$, fluctuating on a monthly average basis between $13.5^{\circ} \mathrm{C}$ and $37.1^{\circ} \mathrm{C}$ in January and July, respectively (Fig. 2). The highest temperature recorded is $48.6^{\circ} \mathrm{C}$. The coldest and hottest monthly temperatures correspond to the winter and summer months; annual precipitation is $194 \mathrm{~mm}$. The wet season, with monthly precipitation exceeding $30 \mathrm{~mm}$, occurs from December to March. The dry season occurs from April to November, with monthly precipitation levels not exceeding $10 \mathrm{~mm}$. The wettest month is February $(46.6 \mathrm{~mm})$, while the driest month is July (1 mm).

The region is influenced by two climatic forcings: Mediterranean and the Indian Ocean Summer Monsoon (IOSM) systems that have varying impacts. The dominant climate is a Mediterranean type, with a short-wet season during winter and almost no precipitation during the hot summer (Blumler, 2005; see Fig. 2). Precipitation is driven by the North Atlantic Oscillation and winter rainfall is determined by changes in westerlies that drive the Mediterranean cyclones towards central Asia (Fallah et al., 2015).
Jiroft $(601 \mathrm{~m})$ 1989-2005

${ }^{\circ} \mathrm{C}$

$26.3^{\circ} \mathrm{C} \quad 194 \mathrm{~mm}$

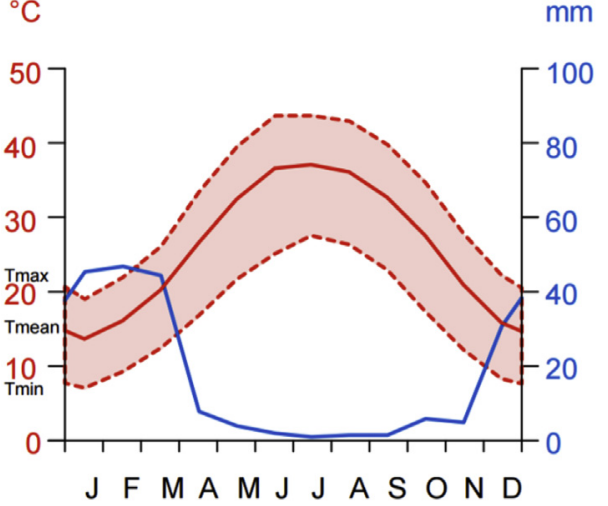

Fig. 2. . Monthly temperature $\left({ }^{\circ} \mathrm{C}\right)$ and precipitation $(\mathrm{mm})$ changes on an annual basis in Jiroft. The dashed red horizontal lines stand for the maximum $\left(\mathrm{T}_{\max }\right)$ and minimum $\left(T_{\min }\right)$ temperature averages; the solid red line in the middle is for mean monthly temperature $\left(\mathrm{T}_{\text {mean }}\right)$. Data accessed from the Iran Meteorological Organization, 1989-2005 (www.irimo.ir). (For interpretation of the references to colour in this figure legend, the reader is referred to the Web version of this article.)

The monsoons have limited influence on annual precipitation because southeastern Iran is located on the terminal NW boundary of the IOSM (Meher-Homji, 1984).

However, climatic conditions were not like this in the distant past. During the mid-Holocene, southeastern parts of Iran are believed to have undergone a dramatic shift from a humid IOSMdriven climate to semi-arid Mediterranean conditions (Fleitmann et al., 2003; Fallah et al., 2015). The Intertropical Convergence Zone (ITCZ) peaked northward position ca. $10 \mathrm{ka}$ resulting in intensive summer precipitation over the whole region. Around 8 $\mathrm{ka}$, the ITCZ started shifting southwards, leading to a decline in monsoon intensity, followed by its final retreat ca. 6-7 ka in southeastern Iran (Fleitmann et al., 2003). The gradual transition to Mediterranean climate was further confirmed by climate modeling, whereby ca. $6 \mathrm{ka}$ Iran witnessed intense winter precipitation (minimal change in summer precipitation implied a complete retreat of monsoons; Fallah et al., 2015). Due to this transition, and northward shift of the West Asian Sub-tropical Westerly Jet, Iran experienced extreme droughts such as the 4.2 ka event that resulted in substantial aridification. The model simulations also predicted that winter rainfall pattern over Iran followed changes in solar insolation resulting in wetter conditions that started ca. $3 \mathrm{ka}$ and reached its maximum during the Medieval Climate Anomaly ca. 1 ka BP (Fallah et al., 2015).

\subsection{Vegetation}

Jiroft lies on the boundary of two significant phytogeographical domains in North Africa and Eurasia (Léonard, 1991, Figs. 1 and 3). On the northern side of the plains, originating in the Kerman Mountains, the vegetation belongs to the Irano-Turanian floristic type. Further to the south, extending up to Lake Jazmurian, the vegetation is defined by the Saharo-Sindian flora (Zohary, 1973; Léonard, 1991, 1993). In the Kerman Mountains, the Irano-Turanian landscape is represented by Amygalus scoparia and Acer monspessulanum subsp. persicum. At $1150 \mathrm{~m}$, the Irano-Turanian vegetation is completely replaced by the Saharo-Sindian flora (Fig. 1). The latter is described as a pseudo-savannah dominated by Prosopis koelziana var. koelziana and Ziziphyus spina-christi (Frey and Kürschner, 1989; Léonard, 1991). 


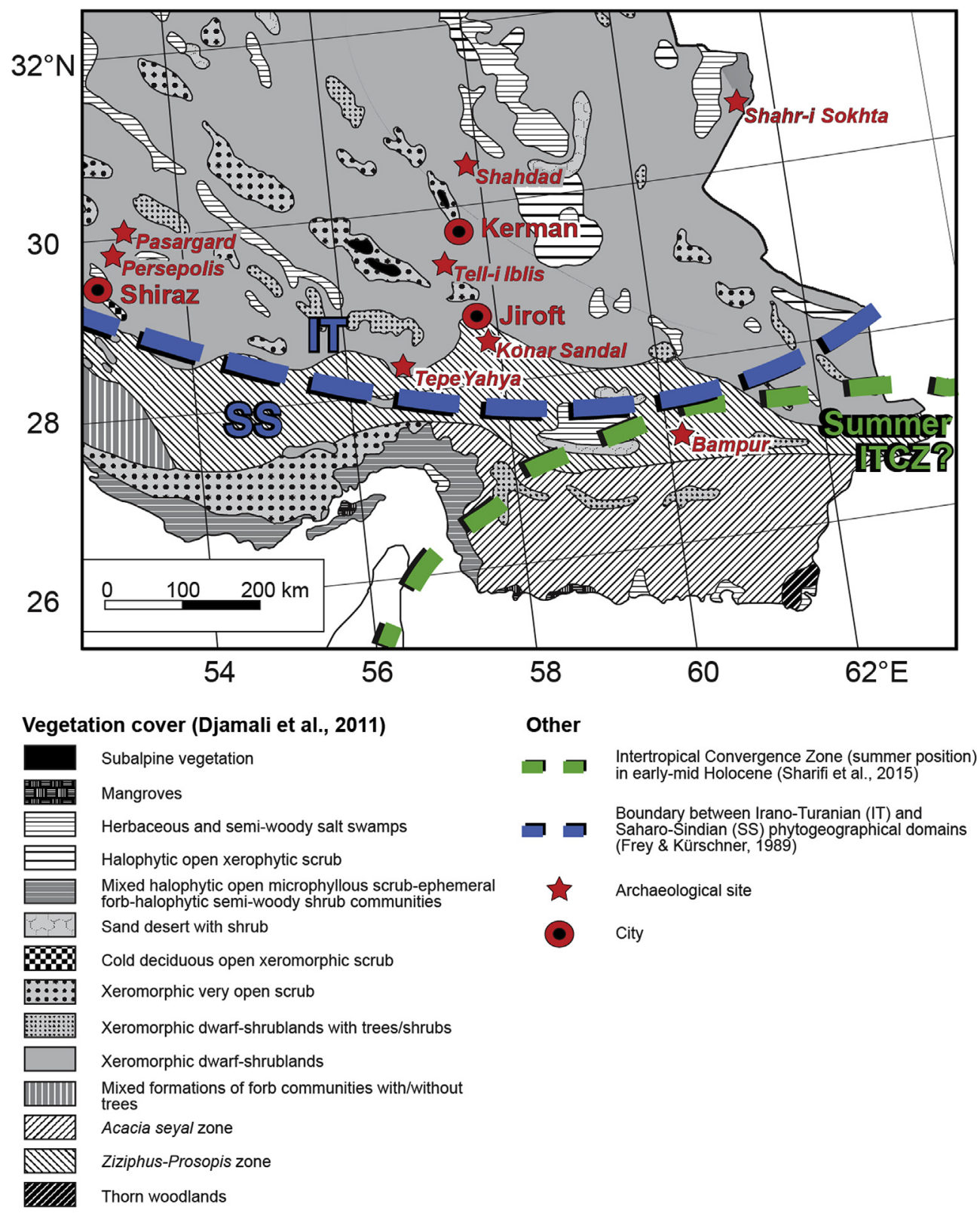

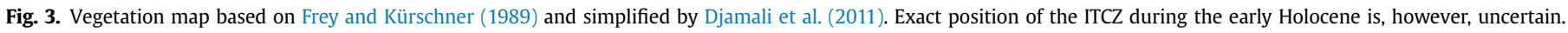

The Jiroft valley has been exposed to strong degradation resulting from livestock (especially goats and camels) trampling the soil, and overgrazing (Mashkour et al., 2013). Such disturbance has facilitated the development of spiny-shrub species, including the commonly present Ziziphus spina-christi. The vegetation in this region is described as relict stands of degraded forests (Léonard, 1991). Such vegetation would have been ubiquitous as far as Lake Jazmurian located ca. $100 \mathrm{~km}$ further south (Léonard, 1991).

At an elevation of $600 \mathrm{~m}$, at the point closest to $\mathrm{KS}(\mathrm{ca} .5 \mathrm{~km}$; Fig. 1) the vegetation is dominated by spiny-shrubs: Rhazia stricta, Prospis koelziana var. koelziana, Lycium depressum subsp. augustifolium, Ephedra foliate, and Calligonum comosum (Léonard, 1991). Further to the south $(500 \mathrm{~m})$, near the city of Kahnooj, there is a significant development of riparian forests (represented by Salix and Tamarix) growing by the river banks and Poaceae grasslands (Léonard, 1991). Agriculture is the main occupation in the region and vast areas surrounding the wetlands around KS have been converted to date palm, orange or cereal (wheat, barley) plantations.

\subsection{Archeology and settlement history}

Systematic excavations commenced in 2001 in KS led by a Franco-Iranian team, with support from scientists from across the world. Most of the on-site artifacts recovered by archeologists and those confiscated by the Iranian government from being smuggled out were the distinct Jiroft-style steatite vessels, often inlaid with semi-precious stones. In addition, there were ceramic ware, inscribed bricks, and clay tablets (Madjidzadeh and Pittman, 2008; Desset, 2014). Remains of domestic and industrial quarters were found at the site during the excavations in KS. Two citadel-like mud-brick mounds, Konar Sandal North (KSN) and Konar Sandal South (KSS), located $1.4 \mathrm{~km}$ apart, are the most remarkable constructions in the area standing on the terraces of the Halil Rud 
(Fig. 1). During the last flooding event, it was observed that while most of the valley was affected by the swirling water in Halil Rud, these mounds, located on the fluvial terraces and built 1-2 m higher than the modern floodplain remained unaffected (Fouache et al., 2005). Such strategic choice for construction of these mounds perhaps signifies the importance of these structures. The function(s) of these structures including the life-size structure of a human figurine may have religious connotation, but their significance in people's lives remain unknown to date (Madjidzadeh and Pittman, 2008). In addition, discovery of platforms with copper slag, tools, and ingots implies that metallurgical activities were common in KS (Madjidzadeh and Pittman, 2008).

Mashkour et al. (2013) carried out bio-archaeological investigations in $\mathrm{KS}$. Besides focusing on evidences related to the historical presence of human settlements in KS (e.g., livestock, agricultural practices, and artefacts), the authors included analysis of charred wood. The study revealed the dominance of two biotopes in the region namely, riparian forests that thrived in the Halil Rud basin characterized by Tamarix, Salix, and Dalbergia sissoo, and the sub-tropical Saharo-Sindian, open shrub- and woodland flora. Mashkour et al. (2013) reported that the riparian forests may have been more abundant than they are at present. These riparian forests represent conditions humid enough to support increased growth, and hence these trees were exploited for firewood and timber. It is possible these trees may have been grown deliberately or harvested. Like the current natural floristic settings, the area was vegetated by Acacia spp., Prosopis cineraria/koelziana, Ziziphus spina-christi, Lycium spp., Salvadora persica, and Amaranthaceae during pre-historic times too. Charred plant remains together with ornamental motifs on steatite vessels reveal that date palm (Phoenix dactylifera) was the main cultivated fruit tree. In addition, grapes (Vitis vinifera) and cereals, free-threshing wheat (Triticum aestivum/durum), and barley (Hordeum vulgare) were also prominent cultivars in KS during the EBA. The settlement was dependent on freshwater supply from Halil Rud, and deposition of fertile sediments on the flood terraces that helped agriculture (Fouache et al., 2005). Main domestic animals comprised of sheep and goats, but also bovines, camels and horses were prevalent in KS (Mashkour et al., 2013).

Most of the artifacts retrieved from KS were dated to the 3rd millennium BCE (2800-2200 BCE) (Madjidzadeh and Pittman, 2008). Fouache et al. (2005) and Madjidzadeh and Pittman (2008) suggested that the Halil Rud valley was abandoned at the end of this period due to desertification. Up until the beginning of 1st millennium BCE, the valley may have been settled by tribal nomads (Madjidzadeh and Pittman, 2008). Dated bioarchaeological artifacts from the KSS site attest a second phase of occupation dating to the end of the 2nd Millennium BCE, and the beginning of the 1 st millennium BCE (Mashkour et al., 2013). Some of the artifacts dated to later periods imply that KS was also an important district during the Islamic era (Madjidzadeh and Pittman, 2008; Mashkour et al., 2013). In fact, Mohammad ibniEbrāhim, in his chronicles written during the 17th century, referred to Jiroft during the Seljuk period (12th century BCE) as a trading center between the East and West. According to his records, goods came from "China, Transoxiana, and Khitây, from Hindustân and Khurâsân, from Zanzibâr, Abyssinia, and Egypt, and from Greece, Armenia, Mesopotamia, and Azharbâyjan" (Ebrāhimb, 1886). Likewise, Marco Polo in his travelogue (around $13^{\text {th }}-14$ th century $\mathrm{BCE}$ ) praised the incredible agricultural production in the Jiroft valley noting the cultivation of rice and cereals, as well as dates and a variety of fruits (Polo, 1997). These historical reports indicate the economic and societal well-being of people in KS and its resilience to adapt itself to the societal and environmental changes. The travelogues indicated that the glory of Jiroft was slowly fading as it was increasingly facing invasions by the Tartars (Polo, 1903).

\section{Materials and methods}

A $250-\mathrm{cm}$ sediment core was obtained from a peat sequence locally named as Daryache (Persian name for lake) near Jiroft $\left(28^{\circ} 27^{\prime} 5.2^{\prime \prime} \mathrm{N}\right.$ and $\left.57^{\circ} 46^{\prime} 49.1^{\prime \prime} \mathrm{E}\right)$. The peat-deposit is located between the raised mounds of KS, i.e., KSN and KSS, ca.1 km to the west from Halil Rud. Coring was carried out in February 2015 using a Russian peat corer. Lithology was recorded in the field by visually assessing the sediments after the core was retrieved and photographed. The core was sectioned into $1-4 \mathrm{~cm}$ intervals, and samples were stored in zip-lock polythene bags. Grain-size was measured every 5-cm using Micrometrics SediGraph III Particle Size analyzer.

Eight samples were sent for AMS radiocarbon dating at the Poznan Radiocarbon Laboratory, Poland to establish the chronology (Table 1). The dated material was bulk sediments. An age-depth model was generated with Clam v. 2.2 (Blaauw, 2010) using IntCal13. The ${ }^{14} \mathrm{C}$ calibration curve used a smooth spline interpolation with spar $=0.35$, 95\% confidence interval and 10000 iterations (Fig. 4).

Thirty-five samples were extracted for palynological analysis at intervals of $1-10 \mathrm{~cm}$. The chemical treatment was conducted adopting the classical pollen extraction procedure standardized by Moore et al. (1991). A single Lycopodium spore tablet (batch nr. 1031) was added to each sample to determine absolute concentrations of pollen and micro-charcoal particles (Stockmarr, 1971). For each sample, the minimum of 300 upland-flora pollen were counted (on average of 320 grains per sample). An exception to this general trend occurred in DAR-20 (the numeric extension refers to sample depth in the core); counting indicated only 128 upland pollen grains, due to extremely low pollen counts. Identification was based on pollen identification keys and atlases (Reille, 1992; Beug, 2004) and the Iranian pollen reference collection established at the Institut Méditerranéen de Biodiversité et d'Ecologie, Aix-enProvence, France. The total pollen sum (TPS) was established by including percentage representation of all identified pollen types; pollen sum (PS) was calculated excluding aquatic plants and Amaranthaceae due to their pervasive abundance that obscure the palynological representation of terrestrial plants.

Magnetic susceptibility (MS) was measured every 2-cm using the Bartington MS2C core logging sensor. Analyzer. X-ray fluorescence (XRF) scanning was performed with a hand-held XRF scanner to detect iron-oxide $\left(\mathrm{Fe}_{2} \mathrm{O}_{3}\right)$ and other elements. Data visualization was performed in C2 software (v. 1.7.2; Juggins, 1991-2011).

\section{Results}

\subsection{Radiocarbon dating}

AMS ${ }^{14} \mathrm{C}$ dating and calibration results are indicated in Table 1 and Fig. 4, respectively. Based on the age-depth model, the core ranged from 3951 cal yr BP (3890-4100 cal yr BP) at the bottom (DAR-250) to $636 \mathrm{cal} \mathrm{yr} \mathrm{BP} \mathrm{(600-800} \mathrm{cal} \mathrm{yr} \mathrm{BP)} \mathrm{at} \mathrm{the} \mathrm{top} \mathrm{(DAR-14).}$ In the deepest section dated at $245 \mathrm{~cm}$, the ${ }^{14} \mathrm{C}$ results indicate an age reversal (by less than a century) against the chronological sequence of the remaining dated samples (Table 1 ). The deepest sample in the core at $245 \mathrm{~cm}$ was $3570 \pm 30 \mathrm{yr}$ BP which is slightly younger then the sample immediately above at $235 \mathrm{~cm}$ at $3655 \pm 35 \mathrm{yr}$ BP. This may indicate a gentle disturbance in sedimentation e.g., as a result of flooding. The model however does not reject the dates and the statistical simulation corrects the age reversal resulting in a basal age of $3935 \mathrm{cal} \mathrm{yr} \mathrm{BP}$ at $250 \mathrm{~cm}$. From 
Table 1

Summary for AMS dating and calibration results in the peat samples from Daryache in Konar Sandal, Kerman province (SE Iran).

\begin{tabular}{|c|c|c|c|c|c|}
\hline Sample no. & Depth $(\mathrm{cm})$ & Lab no. & Age ${ }^{14} \mathrm{C}(\mathrm{yr} \mathrm{BP})$ & Calibrated age (cal yr BP) & Material dated \\
\hline Dar-35 & $34-35$ & Poz-85097 & $1125 \pm 30$ & 1037 & Bulk sediments \\
\hline Dar-64 & $63-64$ & Poz-83152 & $1700 \pm 35$ & 1579 & Bulk sediments \\
\hline Dar-95 & $94-95$ & Poz-83153 & $2130 \pm 30$ & 2139 & Bulk sediments \\
\hline Dar-114 & $113-114$ & Poz-85099 & $2405 \pm 30$ & 2510 & Bulk sediments \\
\hline Dar-143 & $142-143$ & Poz-83154 & $3010 \pm 35$ & 3080 & Bulk sediments \\
\hline Dar-195 & $194-195$ & Poz-83155 & $3400 \pm 35$ & 3672 & Bulk sediments \\
\hline Dar-235 & $234-235$ & Poz-83156 & $3655 \pm 35$ & 3902 & Bulk sediments \\
\hline Dar-245 & $244-245$ & Poz-85100 & $3570 \pm 30$ & 3951 & Bulk sediments \\
\hline
\end{tabular}

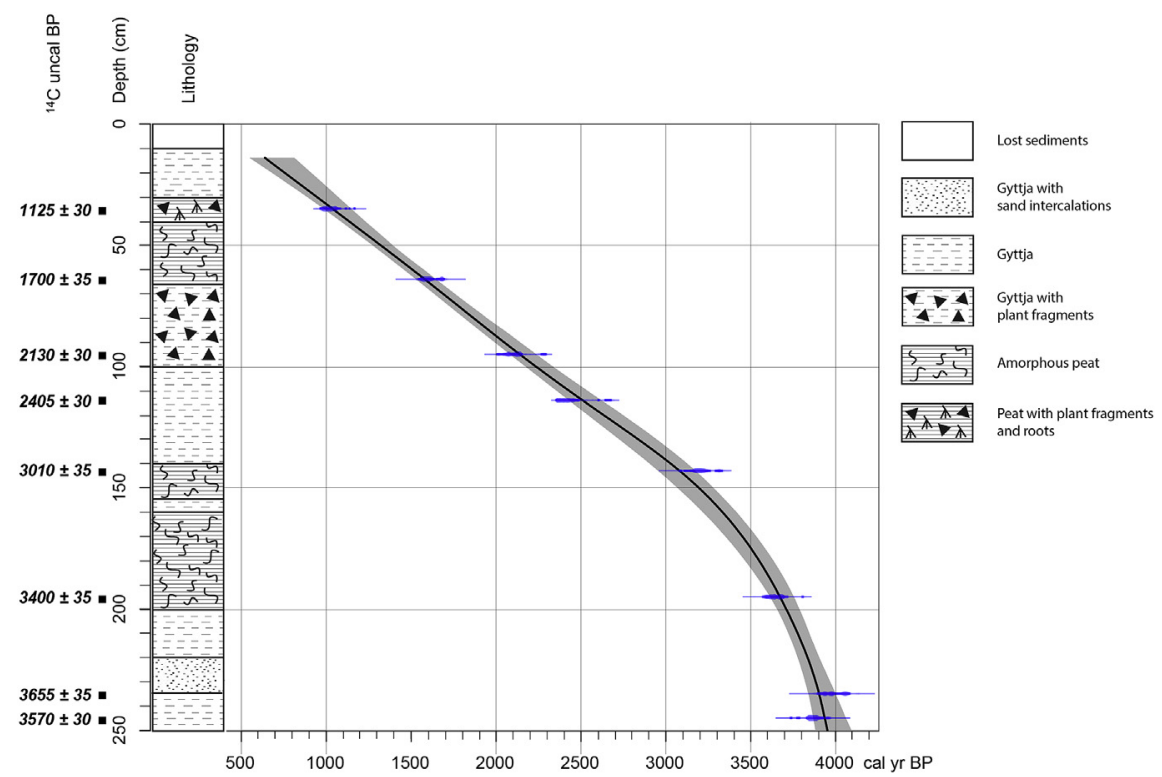

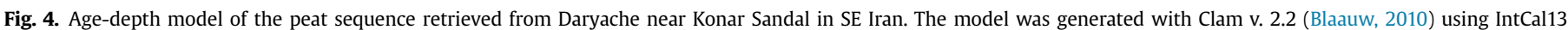

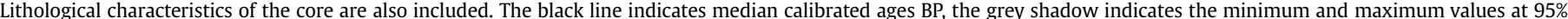
confidence interval.

$235 \mathrm{~cm}$ to $143 \mathrm{~cm}$ sediment accumulation rate in the peat sequence is relatively high (on average $8.9 \mathrm{~cm} / \mathrm{yr}$ ), but gently diminishes core upward. The sediment accumulation rate then appears uniform throughout the remaining core with an average of $18.8 \mathrm{~cm} / \mathrm{yr}$.

The DAR record starts just around or slightly after the proposed demise of Jiroft, when the population is believed to have retreated ca. 4200 cal yr BP. The core extends from the late Bronze Age, through the Iron Age (ca. 1400-1300 BCE), the Persian Empire (ca. 550-650 BCE), the early Islamic period, and ends soon after the Mongol invasion (ca.1219-1221) providing a time capsule of major historical events in the region preserved in the peat sequence.

\subsection{Palynology}

Summary of pollen percentage data are presented in a simplified percentage pollen diagram (Fig. 5). A total of 70 pollen types are identified at 35 depth intervals in the core. These represent 25 trees and shrubs, 38 herbaceous (Fig. 5A), and 7 semi-aquatic and aquatic plant taxa (Fig. 5B). Pollen zonation is based upon pollen assemblages that differ from adjacent zones. For the most part, local pollen assemblage zones (LPAZs) are established with the help of Artemisia and Sparganium-type pollen curves. Disparity in prevalence of these two pollen types within the core indicates changing environmental conditions. In total, 4 major LPAZs were identified, two of which are further divided into sub-zones. Pollen preservation varied in the core and it is related to the lithologic characteristics (see section 4.3). Samples with poor pollen preservation correspond to the presence of gyttja in the peat sequence (Fig. 6); this applies to the sections between 100 and $140 \mathrm{~cm}$ and the very top i.e., between 10 and $15 \mathrm{~cm}$. Poor preservation of pollen also occurs in the deepest section $(>235 \mathrm{~cm})$ of the core. Pollen identification is difficult in these samples partly due to the high load of minerogenic matter, humic substances, and other nonpollen like palynomorphs that are present in high numbers. The sample at $20 \mathrm{~cm}$ depth is exceptionally poor in pollen counts, but rich in micro-charcoal particles $(>10 \mu \mathrm{m})$.

The most abundant pollen type is Amaranthaceae. However, it is difficult to interpret its provenance as some species are halophytic, and the family is ecologically diverse with species preferences from semi-arid to arid conditions (Freitag, 1977). The second most prevalent pollen types are Artemisia and Poaceae.

The most prominent arboreal plant taxon is Prosopis. However, due to the lack of palynological data and reliable identification records in pollen atlases, Prosopis is not identified at the species level. Based on our personal observation of two Prosopis species at the IMBE reference collection ( $P$. farcta and $P$. cineraria) and an earlier botanical survey by Léonard (1991), the arboreal species $P$. cineraria and $P$. koelziana are the most likely species reported for this region. The ruderal sub-shrub $P$. farcta has a more widespread distribution in the Irano-Turanian region of the Kerman region.

The interpretation of pollen assemblages is based upon ecological characteristics of individual pollen types. Wetland 

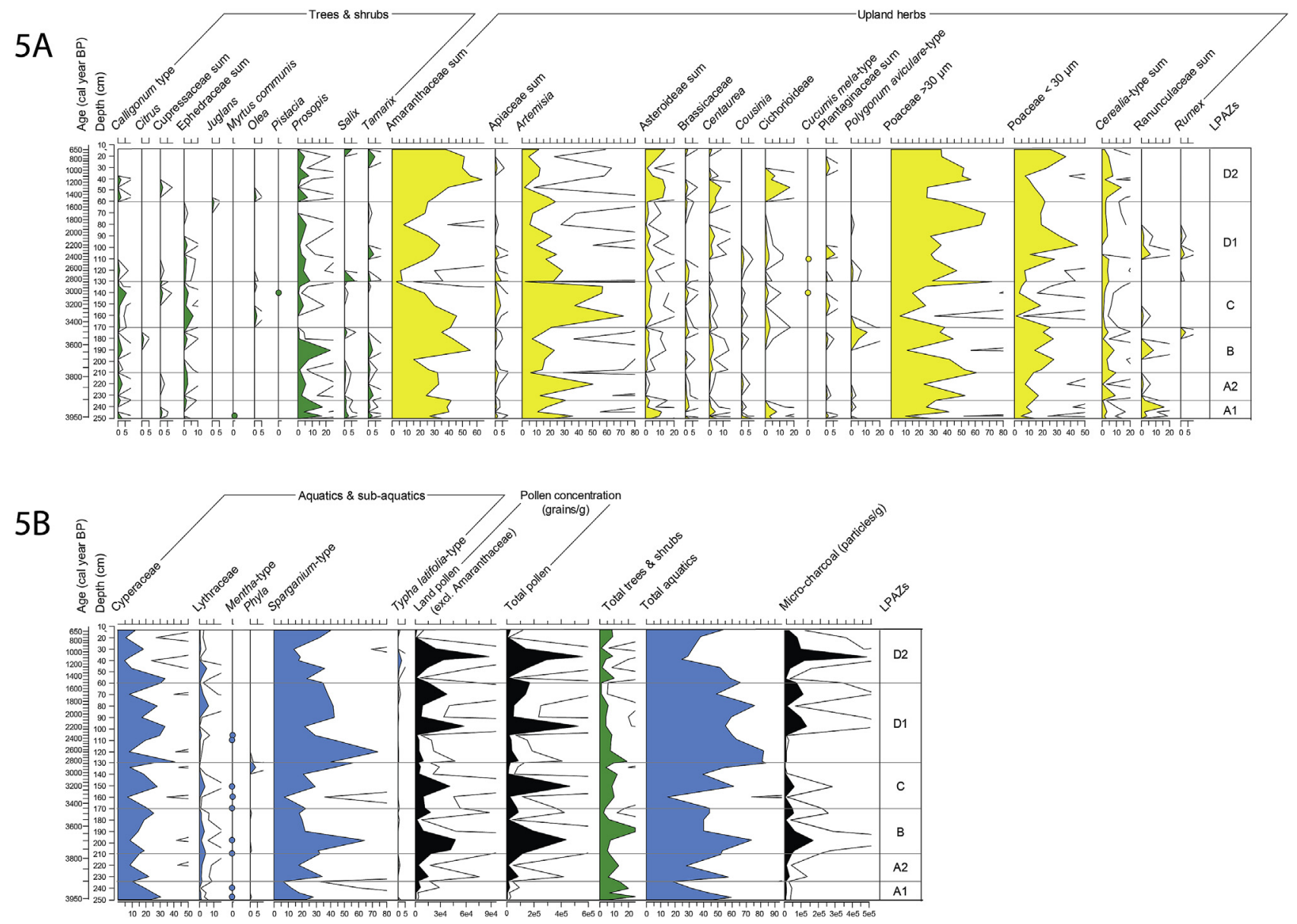

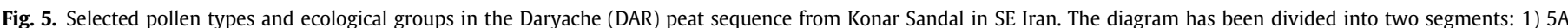

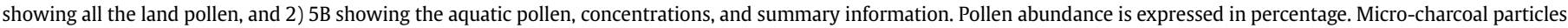

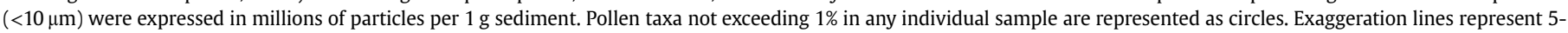
times of the original value (in \%).

hydrological dynamics is interpreted based on the prevalence of aquatic plants (Cyperaceae, Lythraceae, and Sparganium-type). Small Poaceae pollen $(<30 \mu \mathrm{m})$ are believed to be produced mostly by Phragmites, which are local producers (Djamali et al., 2016). The upland plants, predominantly desert shrubs (Calligonum/Pteropyrum and Ephedraceae) and herbs (Artemisia) are crucial for interpreting past regional climates. A low Poaceae/Artemisia ratio indicates drier conditions, while a high ratio indicates wetter conditions (Djamali et al., 2009a; Shumilovskikh et al., 2016). The observed relationship between Artemisia and Poaceae in this study does not conflict with the other proxies, thus higher numbers of Artemisia translate to a shift towards more arid conditions. Pollen from cultivars (Cerealia-type) were investigated in relation to potential agricultural activities in the past. However, due to their relatively low numbers and poor preservation issues, Cerealia-type pollen could not be distinguished to further sub-types. Depending upon pollen assemblages, prevalence of charcoal micro-particles $(>10 \mu \mathrm{m})$ in the intervals is used to interpret greater occurrences of fire, attributing their presence to either anthropogenic burning practices for agro-pastoral activities or naturally occurring forest fires. The extremely high micro-charcoal content can also be indicative of local fires in the wetland.

\subsubsection{LPAZ-A (250-210 cm, 3951-3776 cal yr BP)}

This zone is characterized by moderate frequencies of desert shrubs (Calligonum/Pteropyrum and Ephedraceae) indicative of aridity, aeolian activity, and formation of sand dunes (Zohary, 1973). The distinct peaks of Artemisia accompanied by simultaneous decline in Poaceae $(>30 \mu \mathrm{m})$ may further imply high aridity during this period. Riparian trees (e.g., Salix and Tamarix) are also present. The micro-charcoal levels are low in this zone.

Within this zone, it is possible to distinguish two sub-zones with slightly different floristic characteristics. The pollen composition in LPAZ-A1 (250-235 cm, ca. $4.0 \mathrm{ka})$, features peaks of Prosopis, Asteroideae and Cichorioideae suggesting either aridification and wetland desiccation or extreme soil degradation (Woldring and Bottema, 2013; Zohary, 1973). However, the fact that Prosopis pollen are most probably produced by species other than $P$. farcta, their abundance supports the first hypothesis and prevalence of a very dry period. The wetland vegetation is characterized by the dominance of Cyperaceae over Sparganium/Typha. Such aquatic plant assemblages support desertification rather than a wetter-marsh or swamp-like environment (Djamali et al., 2009b). There are very few pollen from different cultivars in this section, but a single pollen grain of Myrtle (Myrtus communis) was identified. Aeolian transport of the pollen grain cannot be ruled out, but the presence of Myrtle is nevertheless intriguing. Myrtle is a typical Mediterranean plant and its presence suggests either cultivation or proximity to human settlement occurring naturally in the valley. In fact, isolated populations of this tree still thrive in the Kerman Mountains even today (Migliore et al., 2012).

In LPAZ-A2 $(235-210 \mathrm{~cm}, \mathrm{ca} .4 .0-3.8 \mathrm{ka})$ there is a rise in 


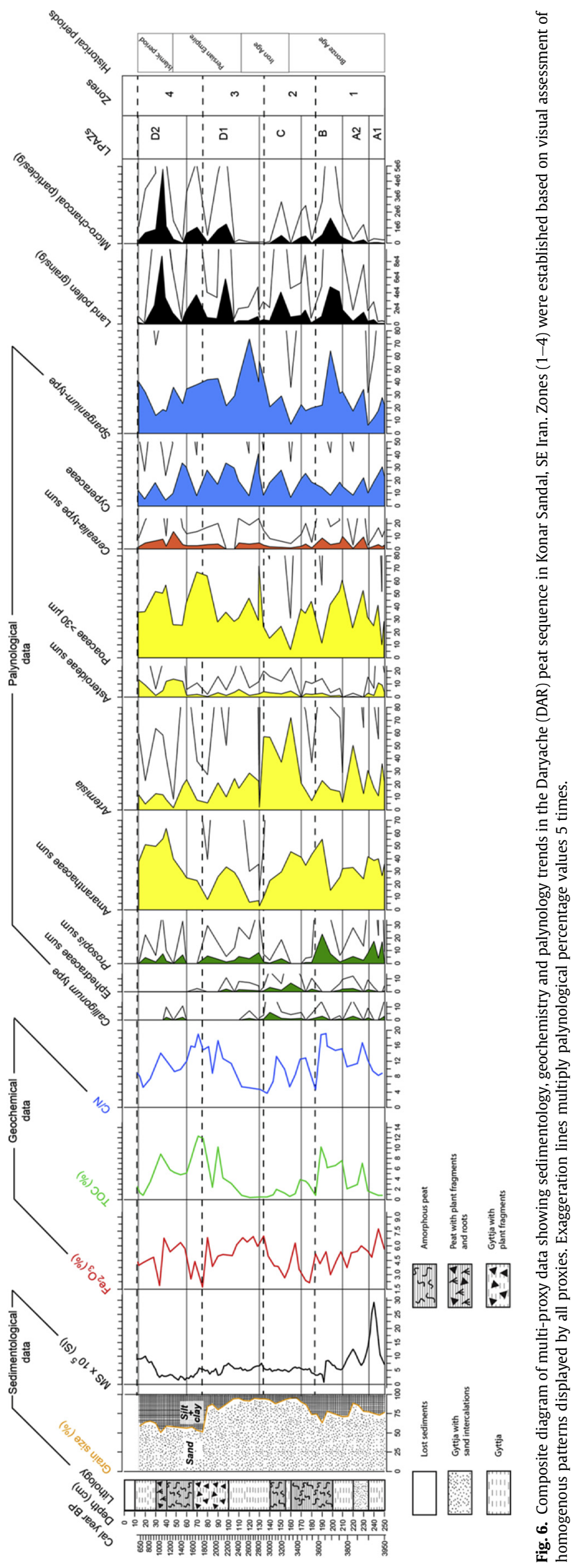

Artemisia and desert shrubs. This zone indicates the first significant appearance of Cerealia-type pollen in the core, indicating cereal cultivation. There is also an increase in Sparganium-type pollen, indicating rising water level (Shumilovskikh et al., 2016). Similarly, to LPAZ-A1, the pollen assemblage in this sub-zone indicates that while the region encountered episodic dry periods, a general increase in water level in the peat deposit is evident.

\subsection{2. $L P A Z-B(210-170 \mathrm{~cm}, 3776-3449$ cal yr BP)}

Regional pollen assemblages show a decrease in Ephedraceae, followed by a dramatic decrease in Artemisia, indicating amelioration of desert-like arid conditions. A peak of Prosopis also occurs during this period. Locally, at the wetland level, towards the beginning of this zone, higher values of Sparganium-type pollen and Poaceae $(<30 \mu \mathrm{m})$ indicate a rise in the water table. However, towards the end, Sparganium-type pollen is replaced by Cyperaceae. Lythraceae is present in significant numbers, suggesting seasonal variation in water table (Daniel Pavon, IMBE, 2017; pers. commun.). Human activities are represented by cereal cultivation during this period as indicated by the high values of Cerealia-type pollen and Centaurea (mostly C. solstitialis-type), a typical weed in cereals (Bottema and Woldring, 1990). Towards the end of this period, cultivation would have shifted to pastoralism corresponding to drier conditions. A small rise in Plantaginaceae and higher values of Polygonum aviculare signal anthropogenic disturbances, such as livestock trampling and overgrazing (Djamali et al., 2009b; Leroy et al., 2013). Increases in micro-charcoal concentrations coincide with Sparganium and occur due to burning of croplands for clearing agro-pastoral land and increasing soil fertility, a practice that is prevalent even today in this region. Overall, this zone may be characterized by milder (less dry and possibly cooler) climatic conditions than in LPAZ-A, and more favourable to be settled by agro-pastoral communities.

\subsubsection{LPAZ-C (170-130 cm, 3776-2836 cal yr BP)}

This zone, like LPAZ-A, has evidence of desert shrubs. There is a peak in Artemisia accompanied by a sharp decline in Poaceae. Towards the lower end of this zone, Prosopis is completely absent, and it retains low values towards the end of this zone. The population of riparian trees is almost absent. Sparganium-type pollen exhibits very low values, and it is replaced by Cyperaceae. Such pollen assemblages may signal aridification and lower water levels in the wetland. The frequency of Cerealia-type pollen is insignificant, showing little evidence of cereal cultivation. A small increase in Plantaginaceae, however, suggests that some ephemeral pastoral communities may have been present. A few Olea pollen were detected in this zone, but these may have been transported over long distances (Woldring and Bottema, 2003) because olive cultivation was unknown during the EBA. In this region, both Olea and Pistacia may have been wild varieties native to this region (Zohary, 1973), and the pollen were perhaps derived from these trees.

\subsubsection{LPAZ-D (130-14 cm, 2836-639 cal yr BP)}

This zone is characterized by substantial decline in Artemisia. There is a continuous presence of Cerealia-type pollen, suggesting an almost permanent occupation by sedentary agrarian communities. Based on the variations in pollen counts of aquatic plants and some upland herbs, the zone can be further divided into two distinct sub-zones.

In LPAZ-D1 (130-40 cm, 2.8-1.1 ka) there is moderate presence of desert shrubs (Ephedraceae) co-occurring with Asteroideae and Cichorioideae. Riparian trees emerge briefly in this sub-zone. The beginning of this sub-zone is marked by the highest abundances of Sparganium-type pollen and Poaceae $(<30 \mu \mathrm{m})$ in the whole record suggesting the highest level of water table in this wetland record. 
Towards the upper end of the sub-zone, there is an increase of Lythraceae accompanied by a decrease of Sparganium-type pollen, suggesting a lower water table. This zone has a characteristic presence of Amaranthaceae with the lowest counts found in the whole sequence occurring towards the beginning of the sub-zone (Fig. 5). The abundance of Poaceae (aquatic and upland steppe) is the highest in this zone. The high values of Poaceae/Artemisia ratio in this interval represent milder conditions. The presence of Plantaginaceae and Rumex imply the existence of pastoralism during this period. In addition, there are at least two short periods that indicate a significant number of micro-charcoal particles coinciding with the disappearance of shrubs that followed afterwards. The decline of arboreal vegetation and increase in fires during more wet conditions favor human settlements, and leads to the increase of biomass burning during the mid-to late Holocene. The fires are likely to have an anthropogenic origin, hinting at human settlements and land-use changes associated with agriculture. This observation in KS is consistent with other studies from the western Mediterranean region (Turner et al., 2008).

In LPAZ-D2 (60-14 cm, 1.5-0.6 ka) Cerealia-type pollen culminates together with Centaurea. The presence of Plantaginaceae implies active pastoralism. Artemisia numbers remain low, and there are no desert shrubs, except for Calligonum that appears briefly. Asteroideae and Cichorioideae pollen reach the highest abundance in this section, suggesting extreme soil degradation or, possibly, episodic desiccation of the wetland. A sharp increase in micro-charcoal concentrations also occurs in this sub-zone. Fires could have destroyed the natural flora which only started recovering towards the end of LPAZ-D2. This is possibly the beginning of land reclamation and exploitation of the wetland, which could explain the signals for desiccation.

\subsection{Sedimentology and geochemistry}

The sub-surface lithology in the peat sequence alternates between gyttja and a more amorphous variety of degraded peat. Gyttja is interpreted as sedimentary material that forms during waterlogging and represents lake or pond-like environments. In contrast, amorphous peat is characterized by high degradation levels that occur during sub-aerial exposure, oxidation, and desiccation due to lower water table in wetlands (Myslinska, 2003). Large size particles (medium to coarse sand; $0.5-1.0 \mathrm{~mm}$ ) in the core result mostly from erosion in the catchment, which in turn occurs due to either higher fluvial discharge (flooding events) or possibly even intensified agro-pastoral practices. In contrast, small particles in the range of silty-sand result from aeolian transport indicating drier and arid conditions. Similarly, MS is often used to infer erosion due to flooding or aeolian activity (Thompson and Morton, 1979). High MS can be associated with increased inputs of terrigenous matter containing iron-bearing minerals during humid conditions or supply of aeolian dust during an arid phase (Patil and Singh, 2013). Consistent with this, the lower part of the core coinciding with higher sediment accumulation rate and input of fine sediments, exhibit high MS values. The high content of silty sand towards the bottom of the core coincides with more aeolian input (e.g. Qiang et al., 2018); this interpretation is also supported by the xeric pollen assemblage (see discussion in section 4.2 ). The increase in MS could be related to the prevailing oxic-anoxic conditions in the peat sequence as indicated by the ferric-oxide $\left(\mathrm{Fe}_{2} \mathrm{O}_{3}\right)$ content, which shows a steady increase towards the top of the sequence. The presence of $\mathrm{Fe}_{2} \mathrm{O}_{3}$ indicates aerial exposure of the peat under drier conditions, indicating that the peat was subjected to oxidative degradation (Nichols, 2009). In contrast, low $\mathrm{Fe}_{2} \mathrm{O}_{3}$ levels indicate anoxic conditions i.e. produced due to waterlogging. Detailed mineralogical assessment of iron chemistry in this core (i.e., formation of iron sulfide, hematite, magnetite and limonite) will help in improving the interpretation of oxic-anoxic conditions, diagenesis and MS trends. The $\mathrm{C} / \mathrm{N}(\mathrm{wt} \%)$ ratio is used to trace the origin of organic matter sources (Meyers and Ishiwatari, 1993). C/N values between 4 and 10 indicate carbon derived from aquatic productivity, while values above 20 indicate organic matter of terrestrial origin i.e., mainly higher plants (Meyers, 1997). Values between 12 and 18 indicate mixed aquatic and terrestrial sources, as well as degradation of organic matter e.g., due to seasonal or inter-annual water-table fluctuation in the peat deposit.

The sedimentological and bulk geochemical paleoenvironmental proxies were grouped into separate zones (1-4) based on the different trends in these sections. These results along with the palynological data are presented together in a composite diagram (Fig. 6).

\subsubsection{Zone-1 $(250-180 \mathrm{~cm}, 3951-3548$ cal yr BP)}

In this zone, the lithology is dominated by gyttja, but it transitions into amorphous peat around $200 \mathrm{~cm}$ (ca. 3700 cal year BP). There is a declining trend of $\mathrm{Fe}_{2} \mathrm{O}_{3}$ level from $\mathrm{ca}$. $8 \%$ to $3 \%$. Fine-size particles consisting of a mixture of silt and clay (up to $62.5 \mu \mathrm{m}$ ) constitute $\mathrm{ca}$. $25 \%$ of the sediments. The sand content remains mostly consistent, but remains slightly lower than the stratigraphic zone immediately above. The MS values reach the highest value of 30 SI between 235 and $250 \mathrm{~cm}$, and they gradually decrease towards the top of this zone. This is the only zone where MS corresponds to $\mathrm{Fe}_{2} \mathrm{O}_{3}$, supporting the interpretation of rising water levels and waterlogging near the bottom of the core representing more humid conditions that changes to dry conditions towards the upper part of this zone. The high MS values at the bottom of the core correspond with the lower values of reed pollen (namely Sparganium-type and $<10 \mu \mathrm{m}$ Poaceae). This indicates that DAR was a small peat deposit that slowly developed due to a rising water table and waterlogging. The peak MS values at the bottom of the core may be indicative of detrital inputs from the river. This signal signifies a change from fluvial to aeolian input of detrital material as MS decreases core upwards, and the input of silty-sand increases. At a later stage in this zone, there may have been an establishment of reeds that grew around the site; such vegetation growth may act as a buffer to the wetland from flood-related sediments. Both TOC and $\mathrm{C} / \mathrm{N}$ show steady increases, whereby aquatic productivity is gradually complemented by rise in terrestrial carbon input indicated by a $\mathrm{C} / \mathrm{N}$ increase from $c a .8$ to 19 . The low $\mathrm{C} / \mathrm{N}$ values in the peat sequence could be due to early post-depositional diagenetic alteration.

\subsubsection{Zone-2 (180-135 cm, 3548-2934 cal yr BP)}

This zone is characterized by very high sand content ( $c a$. 85-95\%), low MS (5 SI), low TOC and C/N ratio (Fig. 6). Overall, the $\mathrm{Fe}_{2} \mathrm{O}_{3}$ levels are low compared to zone 1 except the elevated value of $\mathrm{Fe}_{2} \mathrm{O}_{3}$ at $164 \mathrm{~cm}$ (ca. $3400 \mathrm{cal} \mathrm{yr} \mathrm{BP}$ ) corresponding to the increase in sand content. Overall, productivity is very low in this zone. The wetland was most likely exposed to oxidation (degradation) and desiccation. Oxidation facilitated degradation of organic matter and encouraged the formation of amorphous degraded peat that is prevalent in this zone. MS decreased sharply and remains almost steady until the top of the core (Fig. 6).

\subsubsection{Zone-3 (135-75 cm, 2934-1777 cal yr BP)}

In this zone, $\mathrm{Fe}_{2} \mathrm{O}_{3}$ demonstrates relatively high values, but decreases steadily upwards in the core. Around 100-65 cm depth, undecomposed plant fragments occur, suggesting anoxic conditions in the depositional basin that resulted in good preservation (Fig. 6). At the same time, both TOC and $\mathrm{C} / \mathrm{N}$ ratios increase, denoting an increasing trend in organic productivity. Such an 
assemblage suggests a high-water table and a lower aeolian input. This changeover is supported by accumulation of gyttja in zone 3 .

\subsubsection{Zone-4 (75-14 cm, 1777-639 cal yr BP)}

The wetland experienced higher water level ca. 1.8-1.5 ka, which was followed by a steady decline leading to desiccation. There is a significant decline of sand content in the entire zone, and ca. $40 \%$ of sediments consist of silt and clay, which suggests increasing aeolian activity. The dry conditions during this period resulted in desiccation and greater oxidation of organic matter. This change is supported by the rising $\mathrm{Fe}_{2} \mathrm{O}_{3}$ level followed by a corresponding decline in TOC and C/N ratio between 75 and $40 \mathrm{~cm}$. It is possible that some of these changes may have happened due to human activities, which are indicated by an increase in charcoal peaks from agricultural fires in LPAZ-D2 and a disappearance of aquatic vegetation (see section 4.2.4). The remaining part of the core, $40-14 \mathrm{~cm}$, consists of unconsolidated dry material that has mainly undecomposed plant matter and roots; MS increases slightly from 5 to 10 SI towards the top of the core consistent with the present day dry, windy and arid conditions prevalent around KS (Fig. 6).

\section{Discussion}

\subsection{Hydroclimatic change and landscape evolution in Jiroft valley}

The Mediterranean type climate influence large parts of the Iranian landscape which is affected by the Westerlies. The fluctuations of the Westerlies equator-ward shift or its strength results in precipitation in the southeastern region. The arid to semi-arid landscape, particularly northwestern Iran is also affected by the Siberian Anticyclone and southwestern branch of the IOSM (Sharifi et al., 2015). The winter rainfall pattern in the region indicate a shift from earlier dry condition during the Holocene to wetter conditions that occurred ca. 3-4 ka BP (Fallah et al., 2015). These sweeping climatic changes in the region during the early to mid-Holocene period coincided with the rise and collapse of many EBA settlements in the middle east and Asia. (Staubwasser, 2012). For example, with the shift in climatic conditions and precipitation, Schmidt et al. (2011) indicated that cultural dynamics including human activities clearly changed in the Central Iranian Plateau. The authors compared different lacustrine records and proposed a transition from arid conditions during the early Holocene to humid conditions during the mid-Holocene that coincided with human settlements followed by peak aridity ca. $4.5 \mathrm{ka}$ BP that coincided with a hiatus in human settlements. Similar coincidence of major climatic variations with changing patterns of human occupation, settlement, and cultural changes are also evident in KS, and does not rule out a causative dependency as detailed below.

The period extending from $\mathrm{ca}$. 4.0-2.8 $\mathrm{ka}$ in $\mathrm{KS}$ is mostly dominated by dry conditions. The water table at most times is low, perhaps due to fewer flooding events as suggested by the slow sediment accumulation rate (Fig. 4). Notably, the frequent cycles of episodic droughts are evident from desertification, sand dune formation and spread of xeric vegetation in the Jiroft valley, which correspond to the arid period lasting from the 5th millennia BCE until ca. 2.8-2.7 ka reported in NW Iran by Sharifi et al. (2015) and Shumilovskikh et al. (2016). Sharifi et al. (2015) attribute these droughts to the dominating influence of the Siberian high pressure system on regional climate. It is however difficult to verify if the Siberian Anticyclones had an impact on Jiroft around this period due to its geographical distance from northwestern Iran where its impact was most evident.

During the late Bronze Age ca. 4.0-3.4 ka, the ecosystem however underwent a transition from a shallow peat bog (ca. 4.0-3.9 ka) to a waterlogged wetland ( $c a .3 .8-3.4 \mathrm{ka}$ ) as inferred from the aquatic vegetation and its abundance that has been alternating between dominance of Sparganium-type during wetter conditions versus increase of Cyperaceae during drier conditions. Nonetheless, presence of riparian tree such as Salix in the pollen record during the late Bronze Age implies that climatic conditions were humid enough to support water flow in the Halil Rud, and possibly into the extension of man-made canals and streams. This idea is further supported by the presence of pollen derived from Tamarix spp. in the peat sequence. Pollen production capacity in Tamarix spp. is poor (Freitag, 1977), and therefore its distinct presence in the core means that riparian forests were abundant in the area.

The period around the end of Bronze Age and extending into the Iron Age (ca. 3.4-2.9 ka) is marked by dry conditions as indicated by Artemisia and expanding populations of desert shrubs. The latter is supported by the presence of Calligonum, an indicator for desertification and development of sand dunes (Freitag, 1977; Dehghani et al., 2017). During this period, the water table at KS decreased rapidly, suggesting droughts. The poor water supply was non-conducive for vegetation, and this change is supported by the disappearance of riparian trees that was eventually replaced by Prosopis (Fig. 5). Soon afterwards, from 2.8 to $1.7 \mathrm{ka}$, the dry period was followed by climatic amelioration, and water table in the KS peat deposit rose coeval to increased flooding events in the Halil Rud. Notably, the entire period ( $2.8-0.6 \mathrm{ka})$ is characterized by the spread of Poaceae dominated grasslands. From 2.5 ka onwards, the valley also experienced a decline in desert shrubs, and it gradually shifted to more open degraded landscapes. This trend is similar to the observed changeover to Poaceae-dominated grasslands that has been reported in the Gorgan Plains in NE Iran (Shumilovskikh et al., 2016). Before this, Artemisia and Amaranthaceae were the dominant components in vegetation at KS. However, as a dominant component in the Gorgan steppes, Amaranthaceae was replaced by Poaceae, and the locality became defined as an Artemisia-steppe grassland that existed ca. 2.7-0.7 ka. The development of Artemisia-grassland biomes was attributed to the wetter climatic conditions (Shumilovskikh et al., 2016).

In the absence of regional palaeomonsoon records, it is difficult to quantify if variations in discharge from the Halil Rud were impacted by the IOSM strength and if the resulting flash floods were related to summer precipitation events and rain storms in the Kerman Mountains. The only available record for monsoon-related summer precipitation variations is from stalagmites in Oman which extend from the early Holocene to $0.2 \mathrm{ka}$ (Fleitmann et al., 2007), and in central northwest Iran (Mehterian et al., 2017). Fleitmann et al. (2007) concluded that from 7.8 ka to the present, the ITCZ migrated southward and there was a continuous decline in monsoon intensity and precipitation in response to the overall decline in orbital-induced solar radiation. This overall weakening trend was superimposed on short-lived abrupt changes that occur in many sedimentary archives worldwide. Similarly, the Iranian stalagmite record dating back to rapid climate change during the late Pleistocene to the mid-Holocene indicate enhanced winter precipitation in the interiors of middle east during periods of increased solar insolation (Mehterian et al., 2017). Notably, the decadal to centennial scale $\delta^{18} \mathrm{O}$ record in stalagmites from west Asia used to infer monsoon precipitation correlate well with highlatitude temperature variation in the Greenland ice cores associated with the North Atlantic Oscillations indicating the regional extent of these changes. It is also evident from other Iranian paleoenvironment records that the Mediterranean winter-dominated precipitation was well-established during the period 4 to $0.6 \mathrm{ka}$; including the present study area in KS. Thus, hydrological changes in the Halil Rud system were affected by the hydroclimatic variations that were most likely influenced by the receding IOSM and 
the progressive strengthening of the Mediterranean circulation pattern on a regional scale (Sharifi et al., 2015; Fallah et al., 2015; Djamali et al., 2010).

\subsection{History of agro-pastoralism in Jiroft valley}

While distribution pollen and its abundance in the different sections have been inferred to reconstruct paleovegetation and paleoclimatic conditions in KS, we have been conservative in our assessment and relating this to broad regional changes in sountheastern Iran. We discuss both caveats i.e., pollen concentration and its provenance, which play an important role in interpreting the multi-proxy data. The pollen concentration data has not been used in our case for interpreting the regional vegetation coeval to dry/wet periods. Pollen concentration tends to be higher in more organic-rich sections in the core characterized by peat and undecomposed plant matter (Fig. 6). The opposite trend occurs in gyttja, where the overall content for inorganic material is high and pollen concentrations are low. In addition, abundance of ferric-oxide denotes increased oxidation that correspond to very low pollen concentrations. In such cases, pollen may have been subjected to extreme oxidation and microbial degradation. Hence, the pollen concentration curve is not necessarily representative of regional climatic changes, and it is probably more dependent on sedimentological characteristics related to preservation issues and mineralogical inputs.

The second issue relates to the fact that pollen record obtained from the peat sequence near the KSN archaeological mound is located very close to Halil Rud (less than $1 \mathrm{~km}$, Fig. 1), which historically may have been even closer (Fouache et al., 2005). Halil Rud is occasionally flooded and such flooding events in the past may have deposited pollen from upstream sections of the terrain and per se non-representative of native species growing immediately around KS. The presence of such alien pollen species may complicate the interpretation of local environmental conditions. This especially applies to pollen that have not been observed in regional surveys reported by Léonard (1991) e.g., Juglans, Juniperus, and Pistacia. However, most of dominant pollen species in KS have been observed and reported in other studies, and this gives confidence in the pollen-based reconstruction proposed herein to be representative of southeastern Iran.

The landscape in Jiroft valley ca. 4.0-0.6 ka is explicitly represented by the Saharo-Sindian flora. This assemblage is supported by continuous, although not uniform occurrence of Prosopis pollen. In addition, abundance of aquatic plants (Cyperaceae, Sparganiumtype) in the wetlands contributed to the pollen abundance in the peat sequence at KS. This trend is like the present day modern flora in Jiroft valley (Léonard, 1991, 1993), which includes over $>35 \%$ of endemic Saharo-Sindian species. Based on this, we propose that the landscape throughout the region, during the sampled period, was an open pseudo-savannah vegetation dominated by xerophytic shrubs and trees. The regional vegetation in southeastern Iran is likely to have adapted itself to changing climatic conditions and influenced the Bronze Age settlements. This idea of adaptation in local vegetation to changing climatic conditions and human resilience is documented in various archaeological, paleovegetation, and geochemical studies from the Harrapan sites in SE Asia. Ponton et al. (2012) document a gradual increase in aridity-adapted vegetation type in the Indian sub-continent that prevailed from ca. $4.0 \mathrm{ka}$ to $1.7 \mathrm{ka}$ based on carbon isotope analyses of leaf waxes. The authors claimed that while sedentary agricultural became common in the drier central and southern India, the more urban Harappan civilization collapsed in the Indus basin and people migrated. Eventually, the late Harappan rural settlements became more numerous in the rainier foothills of the Himalayas and the
River Ganges watershed as people migrated and resettled (Sarkar et al., 2016; Madella and Fuller, 2006). Thus, rise in arid conditions may have spurred the widespread adoption of sedentary agriculture, which helped in securing sufficient food in a less secure hydroclimatic regime (Roberts et al., 2016; Asouti and Fuller, 2008). The cultural adaptation to increasing aridity in the Indian subcontinent signifies the increasing resilience in human society and highlights societal response and its capacity to climate stress.

It is not surprising similar adaptation to rising aridity in face of climatic changes is also evident in southeastern Iran. Signs of agropastoralism occur throughout the $4.0 \mathrm{ka}$ record in the Jiroft valley represented in the KS peat sequence. Evidence of agriculture, which would imply a sedentary lifestyle during this period may be inferred by Cerealia-type pollen, most likely represented by wheat or barley that was detected in surveys in Jiroft valley by Mashkour et al. (2013). Cereal cultivation was distinguished throughout most of the studied period, but underwent a decline and coincided with the dry conditions based on the multi-proxy data. For example, declines occurred: 1 ) just after the phase of large scale abandonment of Jiroft $\mathrm{ca}$. 4.0-3.8 $\mathrm{ka}$, which may be linked to droughts, though of lesser magnitude, and 2) ca. 3.5-2.8 ka, when the droughts were possibly more frequent and powerful. These results imply that there was connection between environmental changes and human lifestyle in the Jiroft valley, and droughts in particular, played a major role in affecting the agro-pastoral communities. However, complete abandonment and desertion of the settlement was most unlikely since presence of pollen types such as Plantaginaceae and Polygonum aviculare-type exist even during the arid periods, especially $3.5-2.8 \mathrm{ka}$, indicating the existence of pastoral communities in KS that persisted. In fact, the pollen assemblage supports the idea of extensive pastoralism that existed from ca. 3.6-2.2 ka. Pollen (Ziziphus spina-christi, Polygonum aviculare) identified during this interval are most likely to be associated with trampling by livestock and grazing (Djamali et al., 2009b; Leroy et al., 2013). Thus, harsh climatic conditions may explain the development and continuance of nomadic pastoralist lifestyle that still has deep historic roots in the region even today (Zanjāni and Nejātiān, 2014). The major period of cereal cultivation in the present study extends from the late Iron Age to Islamic periods between 2.8 and $0.6 \mathrm{ka}$. Based on the pollen assemblages (present study), dating of charred cereal grains, and domestic animal bones (Mashkour et al., 2013), it is postulated that a colonization phase occurred ca. 3.0-2.4 ka in KS. This historical phase corresponds to the period coinciding with an increase in grassland and a deterioration of some of the desert type vegetation. The findings thus strengthen the pollen-based evidence for agro-pastoral activities in the region.

Human activities automatically led to alteration of natural vegetation on the landscape. In this connection, cultivation of dates and presence of woody species are interesting issues that supports this idea. Date palm is the most important crop in modern Jiroft. In $\mathrm{KS}$, access to water from Halil Rud, artesian wells, and hot climate are ideal for cultivating date palms. Their presence was documented in the 3rd millennium BCE steatite vessels as well as identified in fossilized charred remains of dates from Jiroft (Mashkour et al., 2013; Tengberg, 2012). While date palms (wild and cultivated varieties) are almost omnipresent in Jiroft and most of middle east since historical times, its pollen is hardly reported because it is deliberately eliminated by people during pollination (Tengberg, 2012). While decline of woody species in the region may be attributed to climatic factors, their exploitation for fuel, wood or timber by humans is almost inevitable. Consistent with this, charred remains of Tamarix have been found in KS (Mashkour et al., 2013). In addition, there is evidence that multiple shrubs and riparian trees were also exploited by prehistoric communities for 
various activities (Margareta Tengberg, pers. comm.). Thus, a decline of woody species coeval to intensive cereal cultivation, as indicated in the pollen records, occurred ca. 2.5-2.1 ka. This change is probably connected to (re)colonization of KSN as inferred from the increased charcoal counts. These observations suggest that the local communities played a key role in shaping and changing their surrounding environment to acquire land for agro-pastoral use.

\section{Conclusions}

The blend of unique phytogeographic, climatic and rich archaeological settings makes the Jiroft valley a very compelling site to study the paleoenvironmental history and humanenvironment interactions in west Asia that is sometimes referred to as the cradle of human civilization. Results obtained from the multi-proxy (palynological, sedimentological and geochemical) investigation, have shown that Jiroft experienced environmental changes from both natural (weakening monsoons and change in ITCZ and Mediterranean precipitation) and human activities associated with agriculture, pastoralism and settlements during the last 4000 years. During the late Holocene, the valley was characterized by Saharo-Sindian pseudo-savannah flora. The landscape shifted from open xerophytic scrub forests to open and degraded scrublands. This transition may be connected to climatic change as well as human activities, i.e., burning and subsequent agro-pastoralism, that later resulted in soil degradation. The role of human activities on the landscape are strongly supported by micro-charcoal particles and cereal pollen that correspond to declining woody and shrub vegetation. Natural environmental changes, mainly in the form of prolonged droughts, may have suppressed agriculture (especially ca. 3.4-2.8 ka, but also around 4.0-2.8 ka) that eventually resulted in successional processes that followed once climatic conditions were more suitable.

The prolonged drought that existed from $\mathrm{ca}$. 4.0-2.8 $\mathrm{ka}$ is probably related to the Siberian anticyclone events. The drought was long, but it was interspersed by wet periods e.g. the one extending from $\mathrm{ca}$. 3.8-3.5 ka that is supported by pollen distribution. The arid phase was indicated by high prevalence of desert shrubs and the dominance of Amaranthaceae and Artemisia. Meanwhile, the period between 2.8 and 0.6 ka records that Amaranthaceae was replaced by Poaceae, with a lower prevalence of Artemisia, and a distinctive deterioration in desert-like vegetation. The sediment record shows that since classical antiquity, but especially during the Islamic period, there was significant human influence on wetland hydrology. Human activities, besides burning and clearance of land, could be narrowed to episodic cereal cultivation. Cultivation of cereals occurs predominantly during the withdrawal of droughts, especially during decolonization of KSN, but also during the Iron Age and the Persian Empire and Islamic periods. Further, the multi-proxy data suggest that pastoralism existed at the site and became more dominant than agriculture in times of harsher climate.

\section{Acknowledgements}

We are very grateful to the support extended by INIOAS for drilling and various logistic help. Naser Ghasemi and Mohammed Ali Hamzeh helped with drilling in Jazmurian and other field related activities. Parisa Habibi helped with the magnetic susceptibility measurements. We thank bother reviewers for the detailed and thoughtful reviews that greatly improved the manuscript. The project was supported from grants provided by Vetenskapsrådet to JR (Grant E0402601).

\section{References}

Asouti, E., Fuller, D.Q., 2008. Trees and Woodlands in South India. Archaeological Perspectives. Left Coast, Walnut Creek, California.

Beug, H.J., 2004. Leitfaden der Pollenbestimmung für Mitteleuropa und angrenzende Gebiete. Pfeil, München.

Blaauw, M., 2010. Methods and code for 'classical' age-modeling of radiocarbon sequences. Quat. Geochronol. 5, 512-518.

Blumler, M., 2005. Three conflated definitions of Mediterranean climates. Middle States Geographer 38, 52-60.

Booth, R.K., Jackson, S.T., Forman, S.L., Kutzbach, J.E., Bettis, E.A., Kreig, J., Wright, D.K., 2005. A severe centennial-scale drought in midcontinental North America 4200 years ago and apparent global linkages. Holocene 15, 321-328.

Bottema, S., Woldring, H., 1990. Anthropogenic indicators in the pollen diagrams of the Eastern Mediterranean. In: Bottema, S., Entjes-Nieborg, G., Zeist, W. van (Eds.), Man's Role in the Shaping of the Eastern Mediterranean Landscape. Balkema, Rotterdam, pp. 231-264.

Dehghani, M., Djamali, M., Gandouin, E., Akhani, H., 2017. A pollen rain-vegetation study along a $3600 \mathrm{~m}$ mountain-desert transect in the Irano-Turanian region; implications for the reliability of some pollen ratios as moisture indicators. Rev. Palaeobot. Palynol. 247, 133-148.

Desset, F., 2014. A new writing system discovered in 3rd millennium BCE Iran: the Konar sandal "geometric" tablets. Iran. Antiq. 49, 159-192.

Dixit, Y., Hodell, A.A., Petrie, C.A., 2014. Abrupt weakening of the summer monsoon in northwest India 4100 yr ago. Geology 42, 339-342.

Djamali, M., Akhani, H., Andrieu-Ponel, V., Braconnot, P., Brewer, S., de Beaulieu, J.L., Fleitmann, D., Fleury, J., Gasse, F., Guibal, F., Jackson, S.T., Lézine, A.M. Médail, F., Ponel, P., Roberts, N., Stevens, L., 2010. Indian Summer Monsoon variations could have affected the early-Holocene woodland expansion in the Near East. Holocene 20, 813-820.

Djamali, M., Akhani, H., Khoshravesh, R., Andrieu-Ponel, V., Ponel, P., Brewer, S. 2011. Application de la Classification Bioclimatique Globale en Iran: implications pour comprendre la végétation actuelle et la biogéographie. Ecol. Mediterr. 37, 91-114.

Djamali, M., Beaulieu, J.-L. De, Miller, N.F., Andrieu-Ponel, V., Ponel, P., Lak, R. Sadeddin, N., Akhani, H., Fazeli, H., 2009a. Vegetation history of the SE section of the Zagros Mountains during the last five millennia; a pollen record from the Maharlou Lake, Fars Province. Iran. Veg. Hist. Archaeobot 18, 123-136.

Djamali, M., Beaulieu, J-L. De, Andrieu-Ponel, V., Berberian, M., Miller, N.F., Gandouin, E., Lahijani, H., Shah-Hosseini, M., Ponel, P., Salimian, M., Guiter, F. 2009b. A late Holocene pollen record from Lake Almalou in NW Iran: evidence for changing land-use in relation to some historical events during the last 3700 years. J. Archaeol. Sci. 36, 1364-1375.

Djamali, M., Jones, M.D., Migliore, J., Balatti, S., Fader, M., Contreras, D., Gondet, S. Hosseini, Z., Lahijani, H., Naderi, A., Shumilovskikh, L.S., Tengberg, M., Weeks, L. 2016. Olive cultivation in the heart of the Persian Achaemenid Empire: new insights into agricultural practices and environmental changes reflected in a late Holocene pollen record from Lake Parishan, SW Iran. Veg. Hist. Archaeobotany 25, 255-269.

Dutt, S., Gupta, A.K., Wünnemann, B., Yanc, D., 2018. A long arid interlude in the Indian summer monsoon during 4,350 to 3,450 cal. yr BP contemporaneous to displacement of the Indus valley civilization. Quat. Int. 482, 83-92.

Dyson Jr., R.H., Voigt, M.M., 1990. Bronze Age, in Encyclopedia Iranica, vol. IV/55, pp. 472-478. http://www.iranicaonline.org/articles/bronze-age. (Accessed 9 July 2018).

Ebrāhim, M.B., 1886. In: Houtsma, M.T. (Ed.), Histoire des Seljoucides du Kermán. Recueil de texts relatifs à l'histoire des Seljoucides, vol. 1. Leiden.

Fallah, B., Sodoudi, S., Russo, E., Kirchner, I., Cubasch, U., 2015. Towards modeling the regional rainfall changes over Iran due to the climate forcing of the past 6000 years. Quat. Int. 429, 1-10.

Fouache, E., Garçon, D., Rousset, D., Sénéchal, G., Madjidzadeh, Y., 2005. La vallée de l'Halil Roud (region de Jiroft, Iran): étude géoarchéologique, méthodologie et résultats préliminaires. Paleorient 31, 107-122.

Fleitmann, D., Burns, S.J., Mudelsee, M., Neff, U., Kramers, J., Mangini, A., Matter, A. 2003. Holocene forcing of the Indian monsoon recorded in a stalagmite from southern Oman. Science 300, 1737-1739.

Fleitman, D., Burnsb, S.J., Mangini, A., Mudelseed, M., Kramersa, J., Villaa, I., Neffc, U., Al-Subbarye, A.A., Buettnera, A., Hipplera, D., Matter, A., 2007. Holocene ITCZ and Indian monsoon dynamics recorded in stalagmites from Oman and Yemen (Socotra). Quat. Sci. Rev. 26, 170-188.

Freitag, H., 1977. The pleniglacial, late-glacial and early postglacial vegetations of zeribar and their present-day counterparts. Palaeohistory 19, 87-95.

Frey, W., Kürschner, H., 1989. Die Vegetation im Vorderen Orient: Erläuterungen zur Karte A VI 1 Vorderer Orient. Vegetation des Tübinger Atlas des Vorderen Orients Reihe A. Dr. Ludwig Reichert, Weisbaden.

Gao, H., Zhu, C., Xu, W., 2007. Environmental change and cultural response around 4200 cal. yr BP in the Yishu River Basin. Shandong. Chin. Geogr. Sci. 17, $285-292$.

Juggins, S., 1991-2011. C2 (Version 1.7.2). Newcastle University, Newcastle.

Lawler, A., 2011. A publication of the Archaeological Institute of America: The Word in between. Archaeology vol. 64. http://archive.archaeology.org/1111/features dasht-e_lut_iran_shahr-i-sokta-shahad_tepe_yaha.html. (Accessed 9 July 2018).

Léonard, J., 1991. Contribution à l'étude de la flore et de la végétation des déserts d'Iran (Dasht-e-Kavir, Dasht-e-Lut, Jaz Murian). Etude de la végétation : Analyse 
phytosociologique et phytochorologique des groupements végétaux (fascicule 10, 1ère partie). Jardin botanique national de Belgique, Meise.

Léonard, J., 1993. Comparisons between the phytochorological spectra of three iranian deserts and those of various surrounding regions. Bull. Jard. Bot. Natl. Belg. 62, 389-396.

Leroy, S.A.G., Kakroodi, A.A., Kroonenberg, S., Lahijanic, H.K., Alimohammadi, H, Nigarove, A., 2013. Holocene vegetation history and sea level changes in the SE corner of the Caspian Sea: relevance to SW Asia climate. Quat. Sci. Rev. 70, $28-47$.

Madella, M., Fuller, D.Q., 2006. Palaeoecology and the Harappan civilisation of South Asia: a reconsideration. Quat. Sci. Rev. 25, 1283-1301.

Madjidzadeh, Y., 2003. Jiroft: The Earliest Oriental Civilization. Ministry of Culture and Islamic Guidance, Tehran.

Madjidzadeh, Y., Pittman, H., 2008. Excavations at Konar Sandal in the Region of Jiroft in the Halil Basin: First Preliminary Report. Iran, vol. 46, pp. 69-103.

Mashkour, M., Tengberg, M., Shirazi, Z., Madjidzadeh, Y., 2013. Bio-archaeologica studies at Konar sandal, Halil Rud basin, southeastern Iran. J. Environ. Archaeol $18,222-246$

Meher-Homji, V., 1984. La limite de l'aire du climat méditerranéen au contact de l'aire du climat des moussons dans le sous-continent indo-pakistanais. Bull. Soc. Bot. Fr. 131, 37-49.

Mehterian, S., Pourmand, A., Sharifi, A., Lahijani, H.A.K., Naderi, M., Swart, P.K., 2017 Speleothem records of glacial/interglacial climate from Iran forewarn of future water availability in the interior of the middle east. Quat. Sci. Rev. 164, 187-198.

Moore, P., Webb, J., Collison, M., 1991. Pollen Analysis. Hodder and Stoughton, London, etc.

Meyers, P.A., 1997. Organic geochemical proxies of palaeoceanographic, palaeolimnologic, and palaeoclimatic processes. Org. Geochem. 27, 213-250.

Meyers, P.A., Ishiwatari, R., 1993. Lacustrine organic geochemistry-an overview of indicators of organic matter sources and diagenesis in lake sediments. Org. Geochem. 20, 867-900.

Migliore, J., Baumel, A., Juin, M., Médail, F., 2012. From Mediterranean shores to central Saharan mountains: key phylogeographical insights from the genus Myrtus. J. Biogeogr. 39, 942-956.

Myslinska, E., 2003. Classification of organic soils for engineering geology. Geol. Q. 47, 39-42.

Nichols, G., 2009. In: Nichols, G. (Ed.), Sedimentology and Stratigraphy, second ed. Wiley-Blackwell.

Patil, S.K., Singh, A.D., 2013. New record of magnetic properties of Late Quaternary sediments from the eastern Arabian Sea (off Goa): inferences on paleoclimate. In: Sinha, R., Ravinds, R. (Eds.), Earth System Processes and Disaster Management, Society of Earth Scientists Series 1. Springer-Verlag, Berlin, pp. 113-122.

Pavon, D., 2017. Personal Communication. Institut Méditerranéen de Biodiversité e d'Ecologie, Aix-en-Provence.

Polo, M., 1903. In: Yule, Henry (Ed.), The Book of Ser Marco Polo, the Venetian, Concerning the Kingdoms and Marvels of the East, third ed. John Murray, London.

Polo, M., 1997. In: Colbert, B., Griffith, T. (Eds.), Marsden, W. (Tr.). The Travels of Marco Polo. Wordsworth Classics of World Literature. Wordsworth Editions Ltd., Hertfordshire.

Ponton, C., Giosan, L., Eglinton, T.I., Fuller, D.Q., Johnson, J.E., Kumar, P., Collett, T.S 2012. Holocene aridification of India. Geophys. Res. Lett. 39 https://doi.org/ 10.1029/2011GL050722.

Qiang, M., Jin, Y., Liu, X., Song, L., Li, H., Li, F., Chen, F., 2018. Late Pleistocene and Holocene eolian sedimentation in Gonghe basin northeastern Qinghai-Tibetian plateau: variability, processes and climatic implications. Quat. Sci. Rev. 132, $57-73$

Reille, M., 1992. Pollen et spores d'Europe et d'Afrique du Nord. Laboratoire de botanique historique et de palynology, Marseille.

Roberts, P. Boivin, N., Petraglia, M., Masser, P., Meece, S, Weisskopf, A., Silva, F, Korisettar, R., Fuller, D.Q., 2016. Local diversity in settlement demography and subsistence across the southern Indian Neolithic-Iron Age transition site growth and abandonment at Sanganakallu-Kupgal. Archaeol. Anthropol. Sci. 8 , 575-599.

Sarkar, A., Mukherjee, A.D., Bera, M.K., Das, B., Juyal, N., Morthekai, P., Deshpande, R.D., Shinde, V.S., Rao, L.S., 2016. Oxygen isotope in archaeological bioapatites from India: implications to climate change and decline of Bronze Age Harappan civilization. Sci. Rep. 6, 26555.

Schmidt, A., Quigley, M., Fattahi, M., Azizi, G., Maghsoudi, M., Fazeli, H., 2011. Holocene settlement shifts and paleoenviornmentals on the Central Iranian Plateau: investigating linked systems. Holocene 21, 583-595.

Sharifi, A., Pourmand, A., Canuel, E.A., Ferer-Tyler, E., Peterson, L.C., Aichner, B., Feakins, S.J., Daryaee, T., Djamali, M., Beni, A.N., Lahijani, H.A.K., Swart, P.K., 2015. Abrupt climate variability since the last deglaciation based on a highresolution, multi-proxy peat record from NW Iran: the hand that rocked the Cradle of Civilization? Quat. Sci. Rev. 123, 215-230.

Shumilovskikh, L.S., Hopper, K., Djamali, M., Ponel, P., Demory, F., Rostek, F., Tachikawa, K., Bittmann, F., Golyeva, A., Guibal, F. Talon, B., Wang, L.C. Nezamabadi, M., Bard, E., Lahijani, H., Nokandeh, J., Rekavandi, H.O., de Beaulieu, J.-L., Sauer, E., Andrieu-Ponel, V., 2016. Landscape evolution and agrosylvo-pastoral activities on the Gorgan Plain (NE Iran) in the last 6000 years. Holocene 26, 1676-1691.

Steinkeller, P., 1982. The question of Marhashi: a contribution millennium, to the historical geography of Iran in the third B.C. Z Assyrol Vorderasi 72, 237-265.

Staubwasser, M., 2012. Late Holocene drought pattern over west Asia. Climates, landscapes, and civilizations. Geophys. Monogr. 198, 89-96.

Stockmarr, J., 1971. Tablets with spores used in absolute pollen analysis. Pollen Spores 8, 615-621.

Thompson, R., Morton, D.J., 1979. Magnetic susceptibility and particle-size distribution in recent sediments of the Loch Lomond drainage basin. Scotland. J. Sediment. Res. 49, 801-811.

Turner, R., Roberts, N., Jones, M.D., 2008. Climatic pacing of Mediterranean fire histories from lake sedimentary microcharcoal. Global Planet. Change 63, $317-324$.

Tengberg, M., Unpublished. The exploitation and use of plants in the indo-iranian borderland during the chalcolithic and Bronze age. In: Madjidzadeh Y., Pittman, H. (Eds.), Jiroft in the Bronze Age - Archaeology of the Halil River basin. The University of Pennsylvania Museum of Archaeology and Anthropology, Pennsylvania.

Tengberg, M., 2012. Beginnings and early history of date palm garden cultivation in the Middle East. J. Arid Environ. 86, 139-147.

Vidale, M., Frenez, D., 2015. Indus components in the iconography of a white Marble cylinder seal from Konar Sandal South (Kerman, Iran). J. Southeast Asian Stud. 31, 144-154.

Weiss, H., Courty, M., Wetterstrom, W., Guichard, F., Senior, L., Meadow, R., Curnow, A., 1993. The genesis and collapse of third millennium north Mesopotamian civilization. Science 261, 995-1004.

Woldring, H., Bottema, S., 2003. The vegetation history of east-central Anatolia in relation to archaeology: the Eski Acigoöl pollen evidence compared with the Near Eastern environment. Palaeohistory 43-44, 1-34.

Zanjāni, H.-A., Nejātiān, M.-H., 2014. KERMAN iii. Population, in Encyclopædia Iranica online edition. http://www.iranicaonline.org/articles/kerman-03population. (Accessed 9 July 2018)

Zohary, M., 1973. Geobotanical Foundations of the Middle East, vols. 1-2. Fischer, Stuttgart. 